\title{
Thermic Attenuation on Concrete Sidewalk under Urban Trees. Case Study: Santa Marta - Colombia
}

\section{Carlos Devia}

Facultad de Estudios Ambientales y Rurales Pontificia Universidad Javeriana Bogotá, Colombia

cdevia@javeriana.edu.co

\author{
Andrés Torres \\ Facultad de Ingeniería \\ Pontificia Universidad Javeriana \\ Bogotá, Colombia \\ andres.torres@javeriana.edu.co
}

\section{Abstract}

Background and purpose: Urban trees provide a number of services including shade and thermal attenuation. This is related to morphological and physiological characteristics of trees and may vary between species and even between individuals of the same species. The aim of this work was to identify thermic attenuations on concrete sidewalks under six tropical urban trees with six different types of shadows.

Materials and methods: In Santa Marta City, Colombia $\left(10^{\circ} 12^{\prime} 20^{\prime \prime} N, 74^{\circ} 13^{\prime} 33^{\prime \prime} W, 10\right.$ meters above sea level and $31^{\circ} \mathrm{C}$ temperature), we selected six trees (species) with different types of shade, and they are evaluated for soil temperature and the temperature in the shade and off throughout the day for four different days of the year. ANOVA and t-tests were performed with $R$ program in order to identify the influence of the specie, the day, the hour and the position (at the thermic comfort level, surface temperature) on the temperature results obtained.

\section{INTRODUCTION}

Urban trees provide a number of services including carbon and pollutants capture [1] shade, thermal attenuation and ultraviolet (UV) protection [2, 3] as well as hydric regulation [4].

Heat islands are a consequence of direct sun light effects over city structures. These structures take sun energy and convert it into heat, generating an increase of average city temperature in comparison with nearby rural areas [5]. Trees can reduce temperature by thermic attenuation depending on the shape of their shadows and other physiologic factors such evapotranspiration [6] and nastic movements [7]. Thermic attenuation by trees as an ecosystem service for whole city [8] can range from $0.5^{\circ} \mathrm{C}$ to $1.4^{\circ} \mathrm{C}$ [9, $10]$. These attenuations increase the service life of
Results and conclusion: Some trees have the most translucent shadows most likely due to nictinastic movements and consequently less temperature attenuation. On the other hand, other trees have denser shadows and can generate more substantial thermic attenuations. Regarding temperature data, the hour of the day shows the greatest influence on the variability of air temperature and the species shows the greatest influence on the variability of surface temperature. Honey berry (Meliccoca bijugatus) and Malay almond (Terminalia catappa) trees have denser shadows and can generate more substantial thermic attenuations. Tree physiology can play an important role in temperature attenuation in cities as a result of shadow effects and can be applied as a criterion to select urban trees in tropical cities.

Keywords: Tropical trees, temperature, shadow, heat islands, urban trees

urban surface materials [11-13]. For example, asphalt roads can reach temperatures over $70^{\circ} \mathrm{C}$ without shadow effect causing a reduction in the life cycle of this kind of surface and inducing other effects such as the release of toxic - mutagenic gases [14, 15].

The aim of this work was to identify thermic attenuations on concrete sidewalks under six tropical urban trees with six different types of shadows in Santa Marta city, Colombia.

\section{MATERIALS AND METHODS}

This research was developed in Santa Marta City, Colombia $\left(10^{\circ} 12^{\prime} 20^{\prime \prime} \mathrm{N}, 74^{\circ} 13^{\prime} 33^{\prime \prime} \mathrm{W}, 10\right.$ meters above sea level) (Figure 1), which has an average temperature of $32.6^{\circ} \mathrm{C}$ (Figure 2), and $443 \mathrm{~mm}$ of rain per year (Figure 3) [16]. 


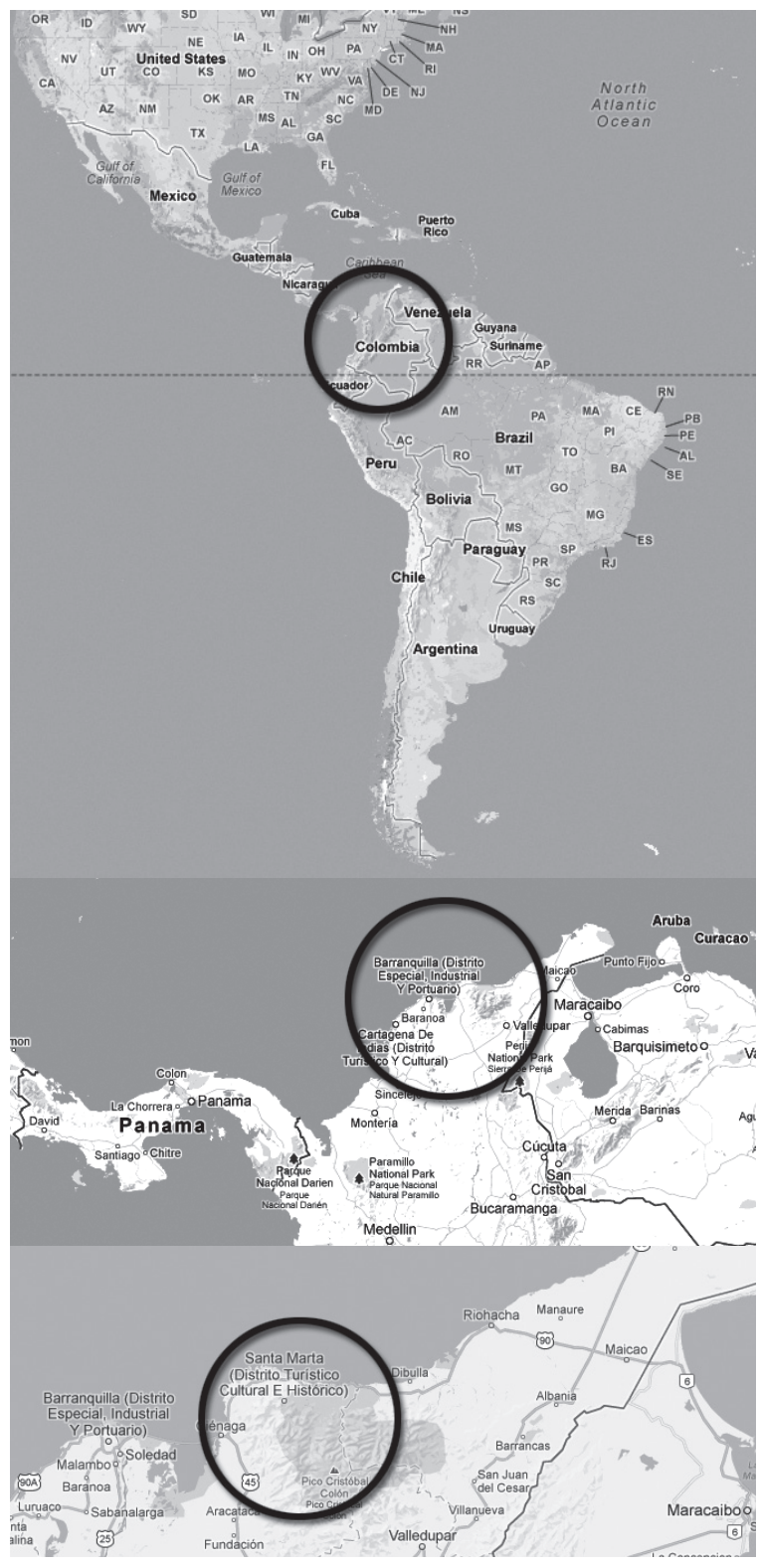

FIGURE 1

Santa Marta Colombia location

TABLE 1

Dendrometric information of selected trees

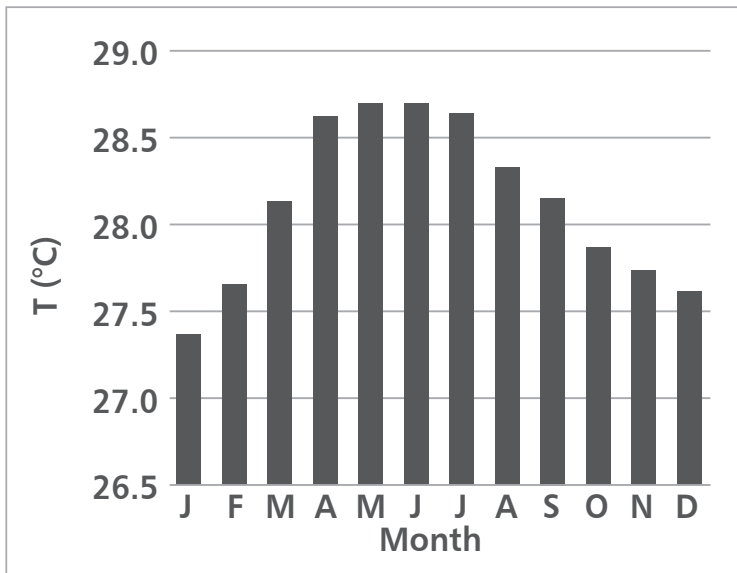

FIGURE 2

Medium temperature $\left({ }^{\circ} \mathrm{C}\right)$

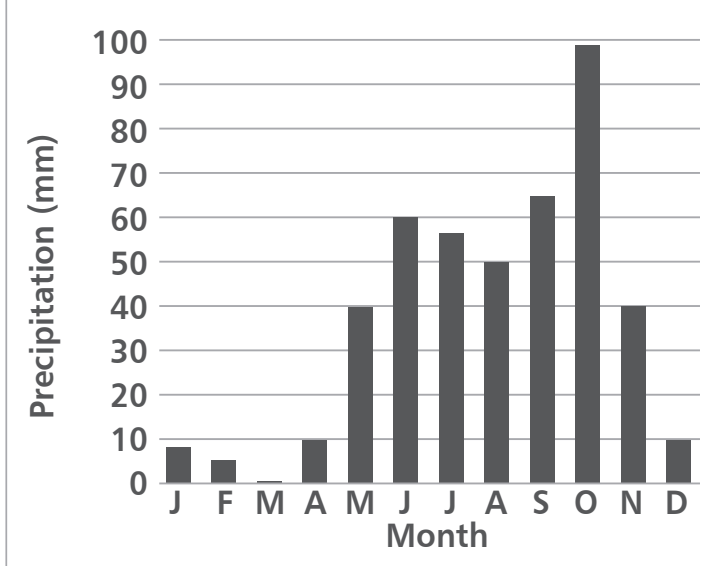

FIGURE 3

Precipitation value

We selected six different kinds of shadows - six trees (Figure 4-9) and five different species: Malay almond 1 and Malay almond 2 (Terminalia catappa), Honey mesquite (Prosopis juliflora), Honey berry (Meliccoca bijuca), Redwood tree (Platysmincium pinatum) and Rain tree (Enterolobium ciclocarpum).

The trees chosen have between 8 and 12 meters (high total), 21 and $45 \mathrm{~cm}$ diameter trunk and between 4 and $8 \mathrm{~m}$ diameter of crown (Table 1).

\begin{tabular}{|l|c|c|c|c|c|}
\hline \multicolumn{1}{|c|}{ Tree } & $\begin{array}{c}\text { Total height } \\
(\mathrm{m})\end{array}$ & $\begin{array}{c}\text { Crown height } \\
(\mathrm{m})\end{array}$ & $\begin{array}{c}\text { Crown diameter } \\
(\mathrm{S}-\mathrm{N} \text { direction) }(\mathrm{m})\end{array}$ & $\begin{array}{c}\text { Crown diameter } \\
(\text { W-E direction) }(\mathrm{m})\end{array}$ & $\begin{array}{c}\text { Diameter at breast } \\
\text { height }(\mathrm{cm})\end{array}$ \\
\hline Malay almond 1 & 8.0 & 4.0 & 6.0 & 5.0 & 25 \\
\hline Honey mesquite & 8.0 & 4.0 & 8.0 & 7.0 & 21 \\
\hline Malay almond 2 & 7.0 & 3.0 & 8.0 & 6.0 & 22 \\
\hline Honey berry & 7.0 & 3.0 & 5.0 & 5.0 & 25 \\
\hline Redwood tree & 6.0 & 3.0 & 4.0 & 4.0 & 25 \\
\hline Rain tree & 12.0 & 5.0 & 8.0 & 7.0 & 45 \\
\hline
\end{tabular}




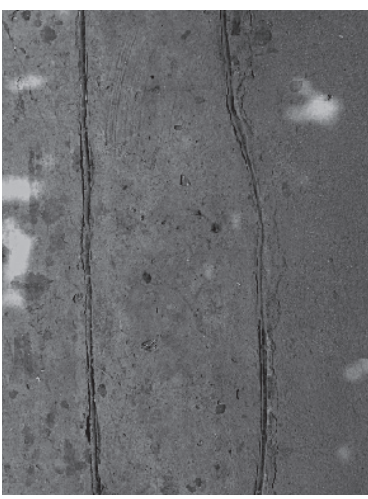

FIGURE 4

Malay almond's

shadow

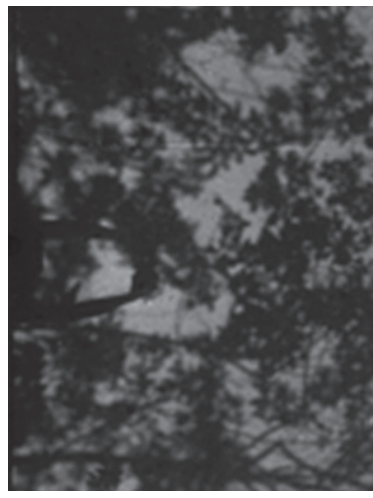

FIGURE 8

Redwood tree's

shadow

Temperature data were collected at the thermic comfort level $(1.5 \mathrm{~m})$ beneath the trees and on the sidewalk at points affected and not affected by the tree's shadow, for day we took temperature with eleven measurements per hour (each $5 \mathrm{sec}$ for a minute) between 8:00 a.m. and 5:00 p.m. over 4 days (March 13 and 26 and April 6 and 7), for a total of 5720 values. For each tree we started with air temperature and in second place we took the surface temperature under the shadow. Finally we took the surface temperature in direct sun light. The value of temperature was taken with an air thermometer (Sper Scientific Mini Environmental Quality Meter), with a resolution of $\pm 1.2^{\circ} \mathrm{C}$ ambient, and surface thermometer (Extech ${ }^{\circledR}$ High Temperature IR Thermometer), with a resolution of $0.1^{\circ} \mathrm{F} /{ }^{\circ} \mathrm{C}$.

ANOVA and t-tests were performed with $\mathrm{R}$ program in order to identify the influence of the specie, the day, the hour and the position (at the thermic comfort level, surface temperature) on the temperature results obtained.

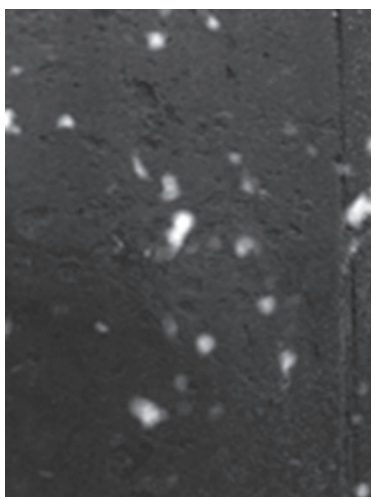

FIGURE 6

Malay almond's

2 shadow

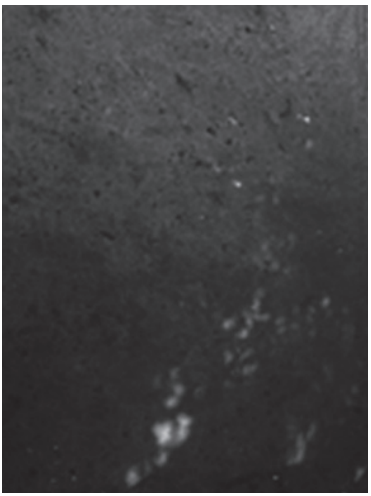

FIGURE 7

Honey berry's shadow

\section{RESULTS AND DISCUSSION}

The average comfort level temperature was $30.3^{\circ} \mathrm{C}$ and ranged from $30.1^{\circ} \mathrm{C}$ to $34^{\circ} \mathrm{C}$. For the temperature measured at the sidewalk, the average value with shadow effect was $29.8^{\circ} \mathrm{C}$ and ranged from $26.0^{\circ} \mathrm{C}$ and $40.7^{\circ} \mathrm{C}$, while the average value without shadow effect was $40.8^{\circ} \mathrm{C}$ and ranged from $40.3^{\circ} \mathrm{C}$ to $77.2^{\circ} \mathrm{C}$. (Table 2, Figures 10 to 21).

\section{TABLE 2}

Temperature Data

\begin{tabular}{|l|c|c|c|}
\hline \multirow{2}{*}{\multicolumn{1}{|c|}{ Species - Position }} & \multicolumn{3}{|c|}{ Temperature $\left({ }^{\circ} \mathrm{C}\right)$} \\
\cline { 2 - 4 } & min & aver & max \\
\hline Malay almond 1 (air) & 30.1 & 30.0 & 34.5 \\
\hline Malay almond 1 (surface) & 29.1 & 29.9 & 38.1 \\
\hline Honey mesquite (air) & 31.3 & 30.4 & 34.7 \\
\hline Honey mesquite (surface) & 30.0 & 30.8 & 40.7 \\
\hline Malay almond 2 (air) & 30.9 & 29.9 & 34.7 \\
\hline Malay almond 2 (surface) & 26.0 & 29.1 & 36.4 \\
\hline Honey berry (air) & 31.2 & 30.8 & 34.1 \\
\hline Honey berry (surface) & 28.8 & 28.1 & 36.5 \\
\hline Redwood tree (air) & 31.2 & 29.2 & 34.7 \\
\hline Redwood tree (surface) & 29.2 & 31.6 & 40.1 \\
\hline Rain tree (air) & 31.3 & 31.4 & 34.7 \\
\hline Rain tree (surface) & 27.4 & 29.2 & 36.6 \\
\hline & & & \\
\hline Direct sunlight (surface) & 40.3 & 40.8 & 77.2 \\
\hline & & & \\
\hline Total value tree (air) & 30.1 & 30.3 & 34.7 \\
\hline Total value (surface) & 26.0 & 29.8 & 40.7 \\
\hline
\end{tabular}




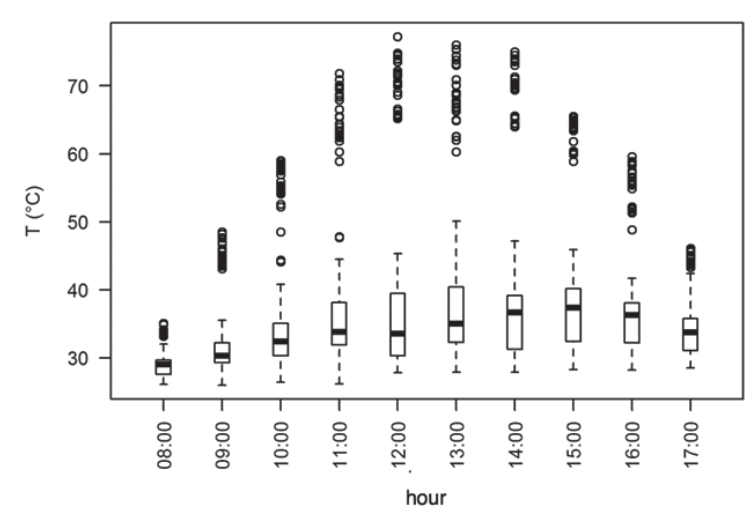

FIGURE 10

Temperature variation along of the day (total values)

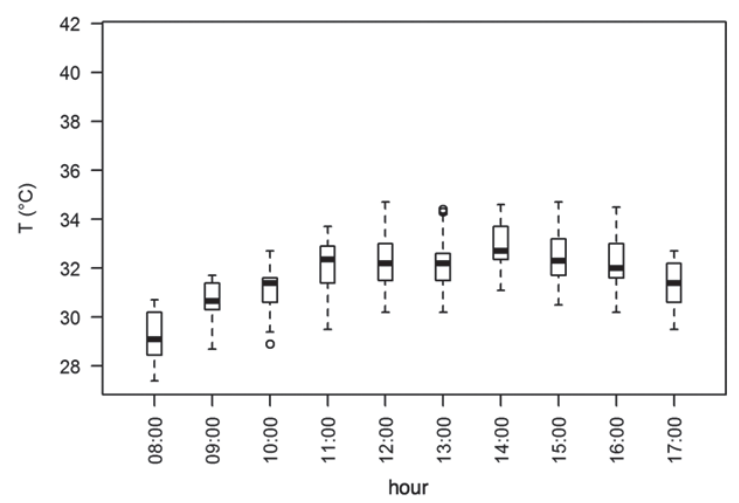

FIGURE 11

Temperature variation along of the day (air values)

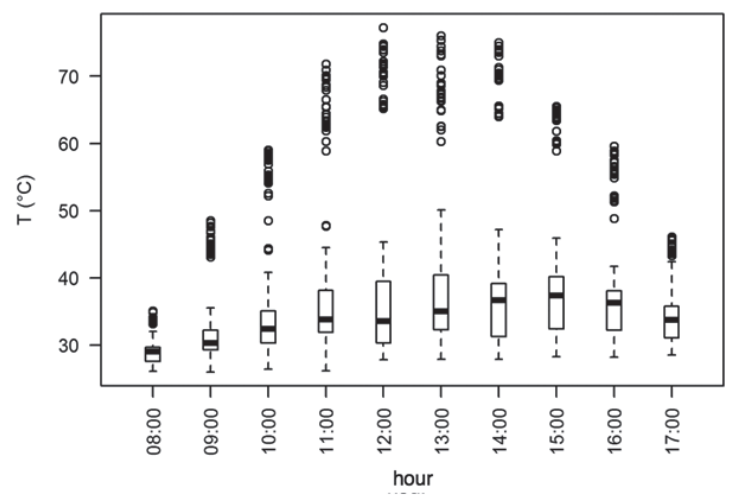

\section{FIGURE 12}

Temperature variation along of the day (surface values)

For temperature collected we applied ANOVA and t-test. ANOVA results indicated that the species (kind of shadow) show the greatest influence on entire temperature variability, followed by the hour of the day, the date and the position (with or without shadow) (Figure 19). The kind of shadow is a primary factor for tree services associated with

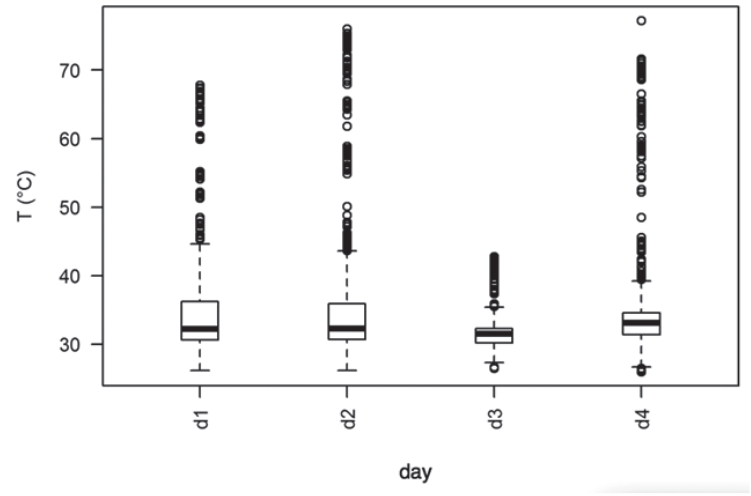

FIGURE 13

Temperature hourly variation (total values)

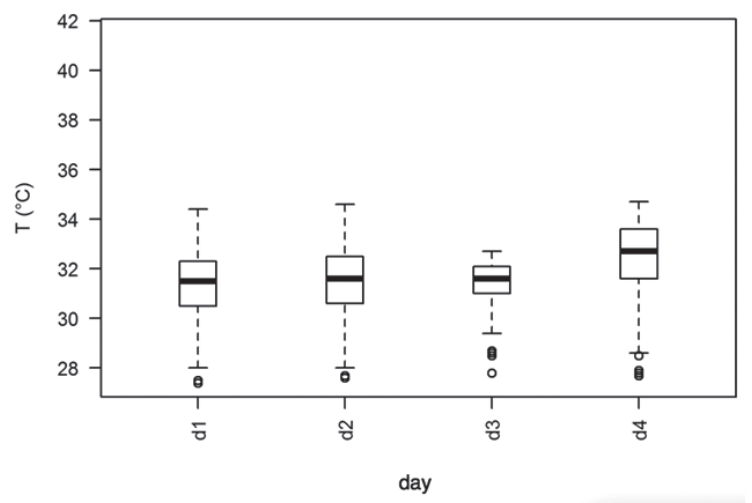

FIGURE 14

Temperature hourly variation (air values)

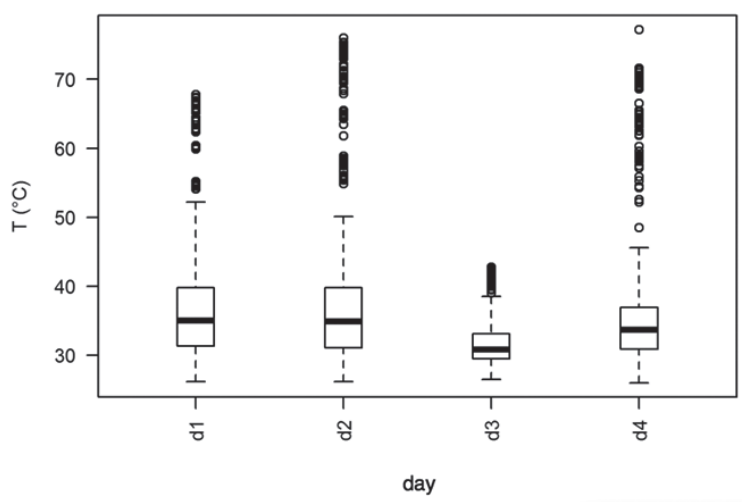

FIGURE 15

Temperature hourly variation (surface values)

thermic attenuation. Regarding temperature data, the hour of the day shows the greatest influence on the variability of air temperature (Figure 19) and the species shows the greatest influence on the variability of surface temperature (Figure 20). These results are of the same magnitude as those reported in the literature for Mediterranean climate 


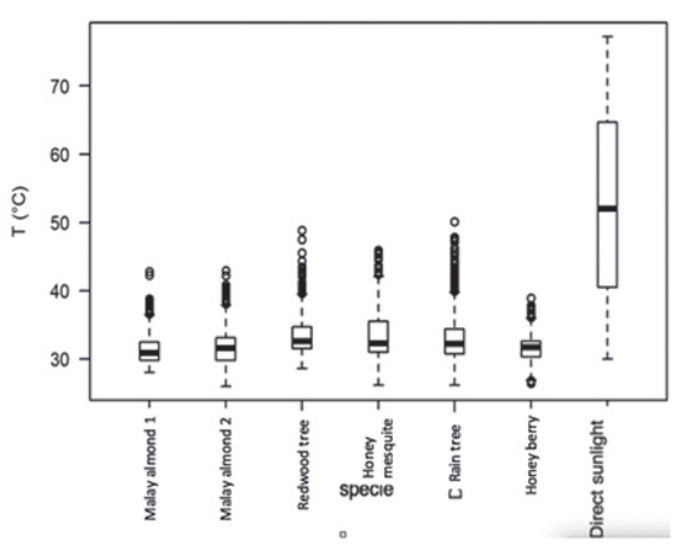

FIGURE 16

Thermic variation by specie (total value)

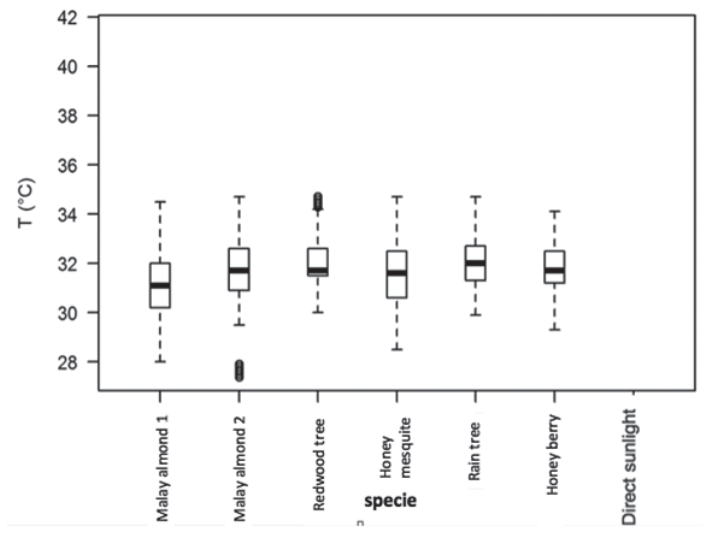

FIGURE 17

Thermic variation by specie (air values)

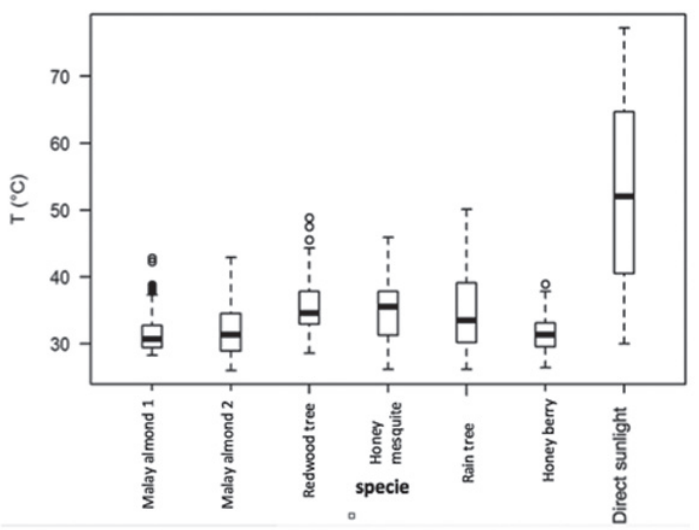

FIGURE 18

Thermic variation by specie (surface values)

$\left(41.3^{\circ} \mathrm{C}\right.$ surface under tree and $63.6^{\circ} \mathrm{C}$ surface direct sun light) [16]. T-test results indicated that the air temperature under the shadow of Malay almond 1 tree vary significantly ( $p$-value $<0.05$ ) from the air temperature results under the shadows of the

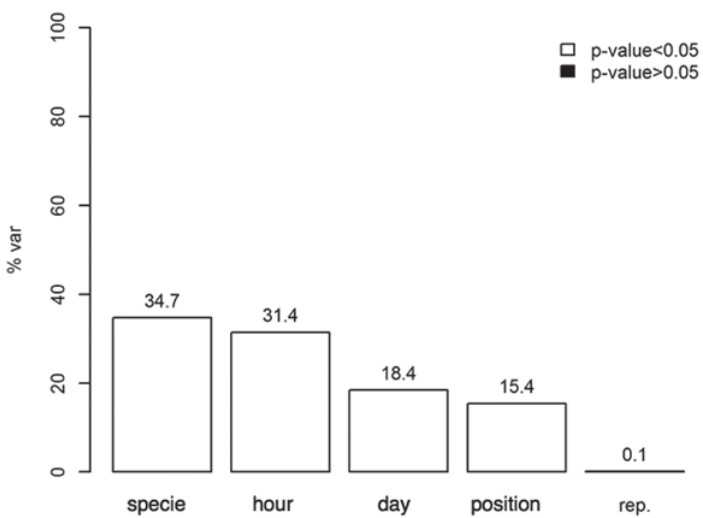

FIGURE 19

Total variance (total values)

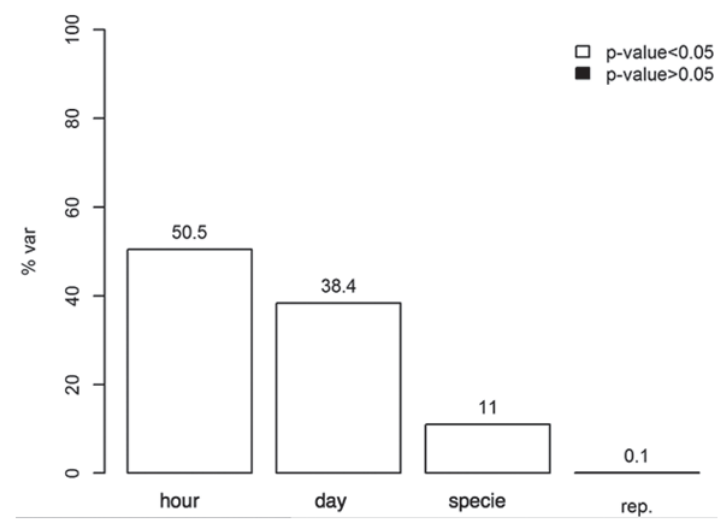

FIGURE 20

Total variance (air values)

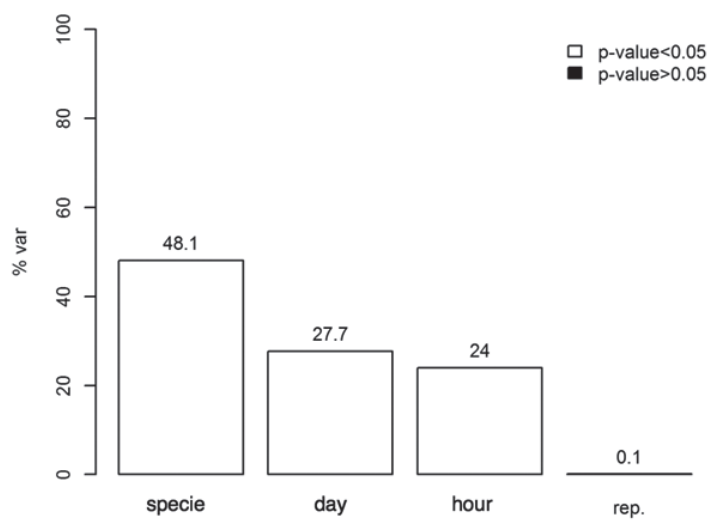

FIGURE 21

Total variance (surface values)

other trees studied, including Malay almond 2. No significant differences between air temperatures under the shadow of Malay almond 2 tree and air temperature related to the other trees were detected (with exception of Malay almond 1) and Honey berry 
TABLE 3

$p$-values from $t$-test species, air temperature

\begin{tabular}{|l|c|c|c|c|c|}
\hline & Malay almond 1 & Malay almond 2 & Redwood tree & Honey mesquite & Rain tree \\
\hline Malay almond 2 & $9.88 \mathrm{E}-17$ & NA & NA & NA & NA \\
\hline Redwood tree & $1.51 \mathrm{E}-24$ & 0.837962096 & NA & NA & NA \\
\hline Honey mesquite & $8.02 \mathrm{E}-09$ & 0.214090457 & 0.00019813 & NA & NA \\
\hline Rain tree & $2.38 \mathrm{E}-28$ & 0.093276126 & 1 & $3.39 \mathrm{E}-06$ & NA \\
\hline Honey berry & $2.68 \mathrm{E}-16$ & 1 & 0.63659583 & 0.294487039 & 0.064964105 \\
\hline
\end{tabular}

\section{TABLE 4}

$p$-values from $t$-test species, surface temperature

\begin{tabular}{|l|c|c|c|c|c|c|}
\hline & $\begin{array}{c}\text { Malay } \\
\text { almond 1 }\end{array}$ & $\begin{array}{c}\text { Malay } \\
\text { almond 2 }\end{array}$ & $\begin{array}{c}\text { Redwood } \\
\text { tree }\end{array}$ & $\begin{array}{c}\text { Honey } \\
\text { mesquite }\end{array}$ & Rain tree & Honey berry \\
\hline Malay almond 2 & $4.47 \mathrm{E}-07$ & NA & NA & NA & NA & NA \\
\hline Redwood tree & $2.75 \mathrm{E}-69$ & $1.44 \mathrm{E}-33$ & NA & NA & NA & NA \\
\hline Honey mesquite & $1.31 \mathrm{E}-42$ & $1.07 \mathrm{E}-15$ & 0.001378591 & NA & NA & NA \\
\hline Rain tree & $2.85 \mathrm{E}-38$ & $4.59 \mathrm{E}-13$ & $4.46 \mathrm{E}-05$ & 1 & NA & NA \\
\hline Honey berry & $6.67 \mathrm{E}-06$ & 1 & $3.20 \mathrm{E}-36$ & $1.49 \mathrm{E}-36$ & $9.13 \mathrm{E}-15$ & NA \\
\hline Surface & $2.82 \mathrm{E}-260$ & $7.50 \mathrm{E}-204$ & $2.39 \mathrm{E}-99$ & $1.35 \mathrm{E}-129$ & $1.14 \mathrm{E}-135$ & $1.31 \mathrm{E}-208$ \\
\hline
\end{tabular}

\section{TABLE 5}

$p$-values from $t$-test especies, hour air temperature

\begin{tabular}{|c|c|c|c|c|c|c|c|c|c|}
\hline & $8: 00$ & $9: 00$ & $10: 00$ & $11: 00$ & $12: 00$ & $13: 00$ & $14: 00$ & $15: 00$ & $16: 00$ \\
\hline $9: 00$ & $2.04 \mathrm{E} 17$ & NA & NA & NA & NA & NA & NA & NA & NA \\
\hline $10: 00$ & $6.33 \mathrm{E}-54$ & $5.51 \mathrm{E}-09$ & NA & NA & NA & NA & NA & NA & NA \\
\hline $11: 00$ & $7.65 \mathrm{E}-90$ & $2.43 \mathrm{E}-28$ & $3.02 \mathrm{E}-06$ & NA & NA & NA & NA & NA & NA \\
\hline $12: 00$ & $1.06 \mathrm{E}-82$ & $3.27 \mathrm{E}-24$ & 0.000342336 & 1 & NA & NA & NA & NA & NA \\
\hline $13: 00$ & $1.75 \mathrm{E}-110$ & $4.29 \mathrm{E}-41$ & $1.23 \mathrm{E}-13$ & 0.596434889 & 0.032186769 & NA & NA & NA & NA \\
\hline $14: 00$ & $1.36 \mathrm{E}-110$ & $3.64 \mathrm{E}-41$ & $1.11 \mathrm{E}-13$ & 0.575694756 & 0.030741969 & 1 & NA & NA & NA \\
\hline $15: 00$ & $6.59 \mathrm{E}-124$ & $6.05 \mathrm{E}-50$ & $1.95 \mathrm{E}-19$ & 0.002970047 & $4.43-05$ & 1 & 1 & NA & NA \\
\hline $16: 00$ & $2.36 \mathrm{E}-108$ & $9.97 \mathrm{E}-40$ & $8.77 \mathrm{E}-13$ & 1 & 0.076710664 & 1 & 1 & 1 & NA \\
\hline $17: 00$ & $7.34 \mathrm{E}-69$ & $1.02 \mathrm{E}-16$ & 0.439815179 & 0.25604151 & 1 & $7.49 \mathrm{E}-06$ & $7.00 \mathrm{E}-06$ & $7.26 \mathrm{E}-10$ & $2.75 \mathrm{E}-05$ \\
\hline
\end{tabular}

offer not significantly difference for other species, the species of Redwood tree and Rain tree significantly similar, the Malay almond 1 tree was significantly different about other trees; the Malay almond 2 tree was not similar to Redwood tree and at the same time significantly different about other trees, however the Redwood tree was significantly different about other trees; Honey mesquite tree was significantly different about other trees as such the Rain tree (Table 3). The Honey mesquite, Redwood tree and Rain tree trees have nictinastic movements and consequently less temperature attenuation. About the surface tem- perature only the Malay almond 2 and Honey berry give same significant of similar conditions (Table 4). The values of air temperature are significant similar for 13:00 and 16:00 hours, 12:00 and 17:00 hours and between 13:00 and 15:00 hours (Table 5). The values of surface temperature are similar significantly between 11:00 to 13:00 hours and between 13:00 and 16:00 hours (Table 6).

Finally about the surface temperature, all trees are significantly different in refer to surface with shadow (direct sunlight). 


\section{TABLE 6}

$p$-values from $t$-test especies, hour surface temperature

\begin{tabular}{|c|c|c|c|c|c|c|c|c|c|}
\hline & $8: 00$ & $9: 00$ & $10: 00$ & $11: 00$ & $12: 00$ & $13: 00$ & $14: 00$ & $15: 00$ & $16: 00$ \\
\hline $9: 00$ & $4.86 \mathrm{E}-35$ & NA & NA & NA & NA & NA & NA & NA & NA \\
\hline $10: 00$ & $3.31 \mathrm{E}-102$ & $7.94 \mathrm{E}-16$ & NA & NA & NA & NA & NA & NA & NA \\
\hline $11: 00$ & $1.95 \mathrm{E}-199$ & $6.40 \mathrm{E}-69$ & $4.10 \mathrm{E}-22$ & NA & NA & NA & NA & NA & NA \\
\hline $12: 00$ & $4.23 \mathrm{E}-192$ & $2.10 \mathrm{E}-64$ & $2.19 \mathrm{E}-19$ & 1 & NA & NA & NA & NA & NA \\
\hline $13: 00$ & $6.55 \mathrm{E}-217$ & $5.69 \mathrm{E}-80$ & $4.04 \mathrm{E}-29$ & 1 & 1 & NA & NA & NA & NA \\
\hline $14: 00$ & $8.26 \mathrm{E}-264$ & $2.09 \mathrm{E}-111$ & $4.75 \mathrm{E}-51$ & $7.95 \mathrm{E}-06$ & $2.17 \mathrm{E}-07$ & 0.007869 & NA & NA & NA \\
\hline $15: 00$ & $1.15 \mathrm{E}-248$ & $5.37 \mathrm{E}-101$ & $1.64 \mathrm{E}-43$ & 0.002392 & 0.000134 & 0.457822 & 1 & NA & NA \\
\hline $16: 00$ & $2.40-228$ & $2.07 \mathrm{E}-87$ & $4.55 \mathrm{E}-34$ & 0.711183 & 0.10442 & 1 & 0.220402 & 1 & NA \\
\hline $17: 00$ & $2.87 \mathrm{E}-138$ & $6.61 \mathrm{E}-34$ & 0.000591 & $9.34 \mathrm{E}-07$ & $2.94 \mathrm{E}-05$ & $6.91 \mathrm{E}-11$ & $1.79 \mathrm{E}-25$ & $3.01 \mathrm{E}-20$ & $5.39 \mathrm{E}-14$ \\
\hline
\end{tabular}

\section{CONCLUSIONS}

For urban surfaces (sidewalks) we found a range of $50^{\circ} \mathrm{C}$ between the lowest value $\left(26^{\circ} \mathrm{C}\right.$ under shadow effect) and the highest value $\left(77.2^{\circ} \mathrm{C}\right.$ under direct sunlight), conditions that can generate positive effects on heat islands and, in the case of asphalt pavements, even a control of toxic vapours and increase in life cycle durability.

Honey mesquite (Prosopis juliflora), Redwood tree (Platysmincium pinatum) and Rain tree (Enterolobium ciclocarpum) trees have the most translucent shadows most likely due to nictinastic

\section{REFERENCES}

1. NOWAK D, CRANE D, STEVENS J 2006 Air pollution removal by urban trees and shrubs in the United States. Urban For Urban Gree 4 (3): 115-123

2. AKBARI $\mathrm{H} 2002$ Shade trees reduce building energy use and $\mathrm{CO}_{2}$ emissions from power plants. [Environ Pollut 116 (1): 119-126

3. HEISLER G M, GRANT R H 2002 Ultraviolet radiation in urban ecosystems with consideration of effects on human health. Urban Ecosyst 4 (3): 193-229

4. FISRWG 2005 Stream corridor restoration. Principles, processes and practices. EEUU: The Federal Interagency Stream Restoration Working Group

5. EPA 2008 Reducing Urban Heat Islands: Compendium of Strategies Urban Heat Island Basics, p 22. Available at: http:// www.epa.gov/hiri/resources/compendium.htm (Accessed: 13 May 2012)

6. OKE T R 1989 The micrometeorology of the urban forest. Philos T Roy Soc B 324 (1223): 335-349

7. SRIVASTAVA L M 2001 Plant Growth and Development. Hormones and Environment. Elsevier Science (USA) Academic press, p 777

8. WHITFORD V, ENNOS A R, HANDLEY J F 2001 City form and natural processes: indicators for the ecological performance of urban areas and their application to Merseyside, UK. Landscape Urban Plan 20 (2): 91-103

9. TYRVÄINEN L, PAULEIT S, SEELAND K, DE VRIES S 2005 Benefits and uses of urban forests and trees. In: Konijnendijk C C, Nilsson K, Randrup T B, Schipperjin J (eds) Urban Forests and Trees. Springer-Verlag, Berlin Heidelberg, pp 81-114 movements and conse-quently less temperature attenuation. On the other hand, Honey berry (Meliccoca bijugatus) and Malay almond (Terminalia catappa) trees have denser shadows and can generate more substantial thermic attenuations. Finally found that there are significant differences between the shadow temperature control (sun light direct) and any temperature under the surface shadow tree.

This information suggests that tree physiology can play an important role in temperature attenuation in cities as a result of shadow effects and can be applied as a criterion to select urban trees in tropical cities.

10. NOWAK D, CRANE D, STEVENS J, IBARRA M 2000 Brooklyn's urban forest. General Technical Report NE-290. Northeastern Research Station, United States Department of Agriculture, Forest Service, Borough of Brooklyn.

11. TRAXLER R N 1961 Relation between Asphalt Composition and Hardening by Volatilization and Oxidation. Proceedings, Association of Asphalt Paving Technologists, Vol. 30, pp 359-377

12. SOARES A L, REGO F C, MCPHERSON E G, SIMPSON J R, PEPER P J, XIAO Q 2011 Benefits and costs of street trees in Lisbon, Portugal. Urban For Urban Gree 10 (2): 69-78

13. MCPHERSON E G, MUCHNICK J 2005 Effects of street tree shade on asphalt concrete pavement performance. Journal of Arboriculture 31(6): 303-310

14. THURSTON R R, KNOWLES E C 1941 Asphalt and its constituents. Oxidation at Service Temperatures. Ind Eng Chem 33 (3): 320-324

15. GAGE S L, ROBERTSON J M, DONNELLY K C, HAGEN A P 1991 Qualitative assessment of the mutagenicity of road coating asphalt. Bull Environ Contam Toxicol 47 (4): 617-622

16. BELLARA S ABDOU S 2013 Benefits and Well-Being Perceived by Pedestrian in Vegetated Urban Space in Periods of Heat Stress. International Journal of Engineering and Technology 5 (1): 20-24

17. CIOH OCEANOGRAFÍA OPERACIONAL 2012. Available at: http://www.cioh.org.co/meteorologia/Climatologia/ ResumenSantaMarta4.php (Accessed: 12 May 2012) 
